Gaulist temperament but also to those who are aware of the practical problems of integrating the physics community. One obvious obstacle is the variation in the character of physical societies from one country to another. Another is the obscurity of many of the organizations which should properly play a part in the development of an integrated society. No doubt it will be several years before the various member societies have enough experience of each other's needs and interests for them to know which parts of their activities can be integrated and which will have to be kept going on a national basis. Until then, however, the organizers of the society see plenty of scope for constructive and common activity, principally in the organization of meetings. It will be interesting to see whether there are funds for financing exchange visits on a significant scale. The problems of journals have not apparently been tackled yet, although there seems to be a view that the ideal solution would be the specialization of existing journals in certain fields of physics. The official headquarters will probably be in Genera.

\section{New Trend in Teaching Science}

Is it possible to teach children engineering? This was the common question asked at the Institute of Electrical Engineers on October 12, when Mr G. B. Harrison, head of the department of creative design at Loughborough College of Education, opened a discussion entitled "The Influences of Changes in School Curricula on the Intake of Engineering Courses".

$\mathrm{Mr}$ Harrison, who is also director of the Schools Council engineering project, began by outlining the aims of the council, which helps children to understand what technology has to offer and trains them to meet the needs of growing up in a society dominated by technology. According to $\mathrm{Mr}$ Harrison, if technology is indeed accepted in schools, the traditional academic attitude of teachers will have to give way to the preparation of new material, apparatus, films, programmes and books that could be discarded when obsolete. He applauded the introduction of engineering as an A-level subject by five of the eight examining boards in the country, but is afraid that diversity might lead to confusion. A common A-level paper is essential so that universities, technical colleges and industry know what is being done at the schools.

An engineering science paper has been introduced by the Northern Universities Joint Matriculation Board to provide an alternative to physics which would meet university requirements. Although the syllabus is similar to traditional physics, it does include project work and practical exercises which demand design ability and creativity. The Oxford Examination Board also has an engineering course. This is, however, to be taken in addition to maths and physics in order to broaden the candidate's horizon. It includes the philosophy of engineering, design aspects and project work. The Cambridge course is essentially mechanical design but also includes the theory of structures and project work. Marks are awarded for project work and added as a bonus to the A-level physics mark. The value of all these courses will depend on the extent to which university courses are geared to work at school. According to $\mathrm{Mr}$ Harrison, the present flow from school to university is a series of acute mis-matches that can only be remedied by a long term reappraisal of the whole educational system.

In view of the importance of the topic, the discussion was sparsely attended, but there were several interesting points raised. Who, for example, is going to teach engineering in schools ? Certainly not the traditionally trained teachers who have passed through training college and who are often accused of being out of touch. Furthermore, as one speaker noted, this is not merely the age of technology, but of change in general: we are no longer living in a static society, and developments should be made in all directions without over-emphasizing any one particular aspect. There was general agreement that a new approach to education is needed and that the attitude of universities and technical colleges towards the acceptance of engineering as an A-level subject should be made clear. Obviously there are many arguments for and against the scheme, but several questions have yet to be answered. For example, have university students benefited by taking engineering at school? What evidence is there that children want technology and engineering in their general syllabus; have headmasters been approached by pupils anxious to study the additional subjects? Perhaps most important of all, has the introduction of engineering in the sixth form been reflected in the numbers reading engineering at establishments of further education? Why not have a census of opinion at all major schools to take into consideration the views of children themselves? All this may be clarified by the working paper, prepared by the Schools Council, which is shortly to be distributed.

\section{Indian Spoken Here}

THE proposed change of language in Indian education away from English prompted Mr Chagla, the Foreign Secretary, to resign early in September. The following week the proposal was discussed at the Conference of Vice-Chancellors in New Delhi, and although the resulting statement published afterwards is in agreement, it contains a certain amount of qualification.

The intention is that English should cease to be the centre of the higher education system, but its importance as a tool is not underestimated. School teaching is at present carried out in regional languages and it is hoped to extend this to undergraduate level. It is realized that a link language is essential, and that the need for a foreign language increases year by year, particularly for library study. Postgraduate courses will continue to be based on English, as translation of books and journals at this level would be impossibly expensive. Regional universities could work on this basis, but all-India institutions raise another problem. Hindi is at present spoken by 40 per cent of the Indian population, but there are some states that are actively against it. Any decision to use it as the education medium in national establishments would therefore have to be made with agreement from non-Hindi states. It is also realized that in multi-lingual cities English may have to be retained as the education medium, alongside the regional languages. The speed and nature of the changes are expected to vary from one university to another, according to circumstances, but undergraduate courses should not take more than 10 years to be adapted. 
The conference approved these proposals, and placed particular emphasis on its endorsement of the statement by the education minister that the criterion for any change-over decision should be an improvement in standards.

\section{Broadcasting Abroad}

LARGELY at the initiative of the Ford Foundation, plans are being canvassed for the setting up of an International Broadcasting Institute intended to ensure that the fullest use is made of technical innova. tions such as Earth satellites. The institute has a distinguished backing, with sponsors such as Dr J. Wiesner in the United States, and Mr Kenneth Younger and Professor Asa Briggs in the United Kingdom. A draft constitution is now circulating, and was indeed discussed in detail at a meeting in New York two weeks ago. The immediate problem is to find financial support for the enterprise, and several foundations have already been approached. To begin with, the institute might consist of a director supported by a small office staff and with a brief to define the field in which a more fully equipped institute might operate. For several reasons, one of which is that non-profit organizations are well treated by the taxation authorities in the United Kingdom, the official headquarters of the institute are likely to be in London.

For the time being, at least, the nucleus of the new institute thinks of itself more as a research organization than a pressure group. It would tackle a variety of problems, such as the way in which broadcasting (principally of television) might be used to provide educational services for developing countries and the legal questions which might arise in broadcasting from one country to another, possibly by means of satellites. Whether the institute would try to engage directly in the issue of just how the new international agreement for INTELSAT should be negotiated is another problem. It also remains to be seen how the institute will be able to define its relationships with bodies, official and otherwise, already operating in this field. Broadcasting networks in Britain and the United States seem to be cool but not hostile.

\section{Social Medicine}

THE only research unit of the Medical Research Council devoted to social medicine is just settling down in its new quarters at the London School of Hygiene and Tropical Medicine. Professor J. N. Morris, formerly the director, becomes honorary director of the unit on his appointment to the chair of public health in the University of London. The unit, consisting of a staff of eleven doctors, statisticians and social scientists as well as clerical staff, moves with him.

Three main topics are being investigated by the unit, which is using the same general methods of statistical analysis, individual and clinical studies for each. Heart disease, particularly coronary thrombosis, has been under examination for about twenty years, with three aims in view: first to discover causes, secondly to find individuals who might be particularly susceptible, and finally to attempt to reduce the risks for these individuals. Using the discovery that high cholesterol levels in the blood point to thrombosis, experiments are being carried out to see if lowering these lipid levels in the blood reduces the incidence of thrombosis among otherwise healthy people. Trial groups in Edinburgh, Prague and Budapest are cooperating in this project. A study is about to be made of men in the civil service to see what effects exercise may have on the incidence of thrombosis. The unit has already established that occupational exercise has a protective value.

In its former home in the East End of London the unit involved itself in local affairs by beginning a survey of juvenile delinquency in that area. No obvious conclusions could be drawn from variations in housing backgrounds, and apparently similar schools produced widely differing delinquency rates. Attitudes within the schools may play an important part, but have yet to be studied. It is hoped that statistical and clinical analyses will lead eventually to a reasonably simple test that can be used by magistrates and probation officers to discover the likelihood of a first offender becoming one of the hard core of delinquents.

Operational research into various aspects of the Health Service forms the third activity of the unit. At present the quality and effectiveness of medical care in different types of hospital are being assessed. Why is it, for example, that teaching hospitals are more effective than others? In this field of everyday medicine it is important to discover causes for variations in the success rates, and a large scale survey of prostate treatment is now being made.

\section{Connective Tissue Clubs Connected}

At the joint meeting of the French and British micropolysaccharide clubs, held on September 29 at the Institut Pasteur, Dr Robert, the secretary of the French. club which initiated this first joint international meeting, proposed that a European Federation of Connective Tissue Clubs should be formed. This was agreed: Professor Kuhn of Munich pledged West German participation. Under the federation the existing national clubs will of course retain their identity and local interests, as well as participate in international meetings. This arrangement should improve on the present situation in which European workers meet each other, if at all, as visitors in the USA. Discussions are now under way in the hope that the return AngloFrench meeting in 1968 , to be held in Britain, will be the first full meeting of the new federation.

At the Paris meeting the magnificent hospitality of Professor Delaunay and the French club provided a perfect background for much productive discussion. Seventeen communications, two of them full lectures by Dr J. T. Dingle and Professor J. Montreuil, wer: given during the day, on the chemistry, metabolism. morphology, embryology and pathology of connective tissue and its components.

The federation, by arranging regular international meetings, should provide new impetus for the European biochemists, pathologists, electron microscopists and many others involved in the expanding field of connective tissue research.

\section{Human Physiology}

THe National Institute for Medical Research seems particularly anxious to make known its work on the 